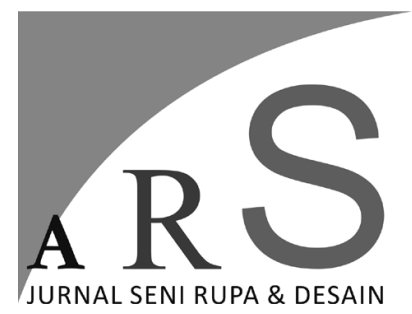

Volume 23 Nomor 1 Januari - Maret 2020

\section{KAJIAN HONEYCOMB PAPER SEBAGAI BAHAN DASAR PEMBUATAN PINTU}

\author{
Yoshua Nico Prasetyo, Jeremy Filbert, Billy Sanata, \\ Gracella Widjaya \\ Program Studi Desain Interior, Fakultas Seni dan Desain, \\ Universitas Kristen Petra \\ Jl. Siwalankerto 121-131, Surabaya 60236 \\ Telepon: 089519561798, E-mail: m41416121@john.petra.ac.id
}

\begin{abstract}
ABSTRAK
Perkembangan desain di dunia pada saat ini sudah sangatlah maju. Honeycomb paper merupakan salah satu inovasi yang menarik untuk menggantikan partikel board, plywood ataupun MDF (Medium Density Fibreboard) dimasa yang akan datang. Salah satu penerapan yang sudah banyak digunakan saat ini adalah sebagai bahan utama dalam pembuatan pintu. Alasan kuat honeycomb paper dapat menggantikan partikel board dan sejenisnya karena, struktur segi 6 (enam) nya yang diadaptasi dari bentuk sarang lebah merupakan salah satu konstruksi dengan tingkat ketahanan paling tinggi. Selain itu honeycomb paper memiliki keunggulan jauh lebih banyak jika dibandingkan dengan MDF, salah satu keunggulan yang sangat terlihat jelas adalah, honeycomb paper jauh lebih ringan jika dibandingkan dengan partikel board, MDF, maupun plywood.
\end{abstract}

Kata kunci: Honeycomb Paper, bahan dasar pembuatan pintu, bahan pengganti plywood.

\begin{abstract}
The development of design in the world today is very advanced. Honeycomb paper is one of the interesting innovations to replace board, plywood or MDF (Medium Density Fibreboard) particles in the future. One application that has been widely used today is as a main ingredient in making doors. The strong reason honeycomb paper can replace board particles and the like is because its 6-sided structure adapted from the honeycomb shape is one of the construction with the highest level of durability. In addition honeycomb paper has far more advantages when compared to $M D F$, one of the very obvious advantages is, honeycomb paper is much lighter when compared to particle board, MDF, and plywood.
\end{abstract}

Keywords: Honeycomb Paper, basic material for making doors, substitute for plywood 


\section{Pendahuluan \\ Latar Belakang}

Kertas merupakan bahan yang tipis dan rata yang biasanya terbuat dari kayu, sering digunakan untuk berbagai kepentingan misalnya untuk menulis, mencetak, menggambar, dan membungkus. Penggunaan kertas saat ini telah mencapai angka yang sangat tinggi. Ada beberapa jenis kertas antara lain kertas HVS, kertas tissue, kertas minyak, dan kertas seni (art paper). Selama ini dalam pemenuhannya, kertas dibuat dari bahan baku kayu yang diketahui pertumbuhannya sangat lambat. Pertumbuhannya yang sangat lambat mengakibatkan kayu yang sebelumnya digunakan sebagai bahan baku pembuatan kertas menjadi sangat berkurang, selain itu kayu juga menjadi salah satu bahan baku utama untuk pembuatan berbagai macam furniture salah satunya pintu. Hal inilah yang menjadi salah satu faktor penyebab rusaknya kawasan hutan dunia dikarenakan penggunaannya yang berlimpah sedangkan pelestariannya membutuhkan waktu yang sangat lambat atau bertahun-tahun. Pintu pasti ada dan digunakan pada setiap bangunan entah bangunan

Mengingat pertumbuhan yang sangat lambat ini dan kebutuhan akan kertas juga setiap tahunnya semakin bertambah, maka untuk mencapai target yang diminta oleh konsumen para produsen akhirnya melakukan illegal logging yang semakin memperparah keadaan hutan yang sudah mulai kritis.

Selama ini kayu sangat sering digunakan sebagai bahan utama dari produk interior yang banyak digunakan, sehingga kebutuhan akan kayu terus meningkat dari tahun ke tahun. Bahkan pada abad modern seperti sekarang ini peranan kayu dalam kehidupan manusia terus meningkat. Peningkatan jumlah penduduk dan semakin majunya peradaban manusia menyebabkan kebutuhan kayu baik untuk peralatan rumah tangga maupun bahan bangunan semakin meningkat. Secara bersamaan peningkatan pendapatan rata-rata rumah tangga juga akan memperbesar kebutuhan kayu untuk masingmasing rumah tangga. Hal ini dapat dimengerti bahwa kayu memiliki karakteristik tersendiri yang tidak dijumpai pada bahan baku lainnya. Maka dari itu untuk mengupayakan melestarikan lingkungan dilakukan dengan daur ulang kertas yang sudah tidak terpakai atau yang biasa kita sebut limbah kertas tersebut merupakan salah satu cara yang dapat dilakukan untuk membantu menjaga kelestarian kayu.

Produk honeycomb paper ini dapat menggantikan kayu yaitu dapat dilihat dari strukturnya yang berbentuk segi enam sehingga memiliki kekuatan fisik yang kuat namun ringan. Honeycomb paper juga memiliki karakteristik yang bagus sehingga cocok untuk digunakan sebagai konstruksi pintu. Hal tersebut dapat dilihat dengan honeycomb paper memiliki kestabilan yang tinggi dan tidak mudah terjadi perubahan bentuk, kekuatan bendingnya juga optimum, dengan berat beban yang dapat dikategorikan ringan untuk honeycomb kekuatannya sesuai dengan perbandingan berat dari honeycomb paper tersebut, bahan bakunya mudah didapat, memiliki usia penggunaan yang cukup panjang, serta memiliki beban yang dapat dikategorikan ringan jika dilihat dengan ukurannya juga cara merakitnya mudah.

\section{Maksud dan Tujuan Penelitian}

Tulisan ini menyajikan perkiraan penggunaan honeycomb paper sebagai bahan dasar pintu akan jauh lebih berdampak positif dan efektif dan juga sebagai bahan pertimbangan pengganti MDF (Medium Density Fibreboard), plywood karena secara tidak langsung kita telah berpartisipasi mengurangi penebangan hutan.

\section{Kontribusi Hasil Penelitian}

Penelitian ini dimaksudkan untuk dapat berkontribusi dalam membantu melestarikan lingkungan dengan cara mengurangi penggunaan kayu sebagai bahan utama pembuatan pintu. Selain itu upaya ini juga dapat membantu agar penebangan liar dapat dikurangi sehingga hutan tidak gundul dan dapat membantu mengatasi global warming.

\section{Landasan Teori}

Menurut Asih Susanti, (2014), kayu merupakan bahan produk alam, hutan. Kayu banyak dipilih dan digunakan karena memiliki pertimbangan kekuatan serta tampilannya. Kayu mudah diolah dan mudah dibentuk sesuai 
dengan keinginan kita. Akan tetapi yang perlu kita ingat, kayu juga berasal dari alam. Alam yang tidak dapat kita kontrol berdampak pada kualitas bahan, sering kita jumpai bahan baku kayu ini tidak sesuai selalu sempurna. Salah satunya, kayu dapat membusuk karena jamur dan kandungan air yang berlebihan. Sedangkan Honeycomb paper adalah bahan pengganti particle Board, MDF board, termocol ataupun plywood yang ramah lingkungan. (Sumber: https:// alphautamamandiri.com/honeycomb-paper/).

Honeycomb paper diproduksi menggunakan teknologi dan mesin yang memiliki tingkat akurasi yang tinggi sehingga resiko cacat produk akan sangat kecil dibandingkan dengan kayu hasil yang didapat akan selalu konstan walaupun diproduksi secara massal.

\section{Metode Penelitian}

Metode yang digunakan dalam penelitian mengenai kajian Honeycomb Paper sebagai bahan dasar pembuatan pintu merupakan metode penelitian kualitatif, yaitu penelitian yang menganalisis hal-hal yang bersangkutan dengan melibatkan berbagai metode yang ada diantaranya seperti melakukan wawancara kepada pihak yang terkait secara langsung dalam pembuatan produk Honeycomb Paper, melakukan pengamatan terhadap produk tersebut, dan memanfaatkan data-data dokumen yang sudah ada (Moeloeng, 2007:5). Metode tersebut digunakan sebagai suatu usaha dalam bentuk menyelesaikan permasalahan yang terjadi.

a. Metode Pendekatan

Dalam metode pendekatan yang digunakan adalah pendekatan deskriptif yaitu melakukan analisis sampai pada taraf deskripsi. (Moeloeng, 2007:6). Data-data yang dikumpulkan berupa kata-kata ,gambar dan bukan angka-angka. Hal tersebut disebabkan oleh adanya penerapan metode kualitatif (Moeloeng, 2007:11).

b. Metode Pengumpulan Data

Data-data yang digunakan di tulisan ini diperoleh dengan cara:

1. Observasi

2. Studi Pustaka

3. Wawancara

4. Dokumentasi c. Metode Analisis Data

Analisis data adalah tahap yang sangat pokok dalam menyimpulkan hasil dalam suatu penelitian. Dalam menganalisis data diperlukan langkah-langkah yang kritis dan cermat. Peneliti harus memastikan pola analisis mana yang digunakan, apakah analisis statistik atau non-statistik. ( Suryabrata, 1998:40). Penelitian ini menggunakan metode kualitatif yang menghasilkan data deskriptif.

\section{Pembahasan}

Proses produksi pintu honeycomb secara umum :

1. Pertama kita persiapkan terlebih dahulu bingkai kayu atau chipboard. Rangka kayu ini berfungsi sebagai bingkai guna memperkuat struktur pintu.

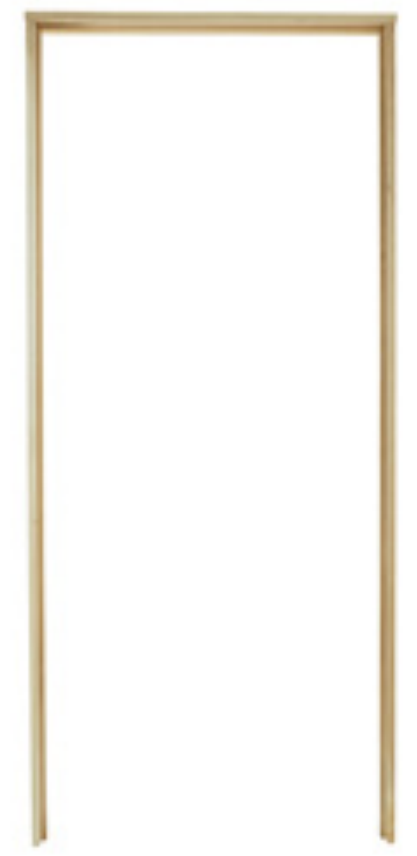

Gambar 1. Bingkai Pintu Kayu

(Sumber : http://singcore.com/news/pre-built-torsionbox-inserts-at-lowes/attachment/how-to-glue-singtorsion-box-available-at-loweswood-frame-2)

2. Kemudian salah satu sisi dari kedua papan HVL (High Visco Laminating) diberi lem. Lem ini berfungsi sebagai media perekat antara bingkai kayu dan papan HVL. 


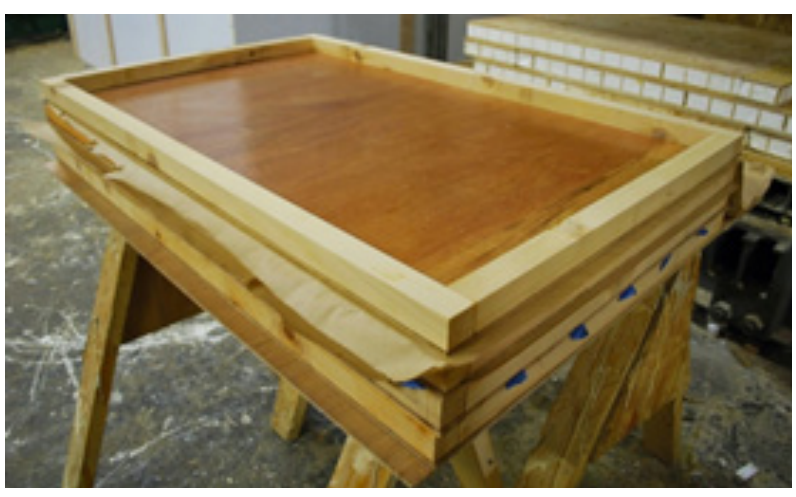

Gambar 2. Proses Pengeleman Bingkai Pintu Kayu Pada Papan HVL.

(Sumber: http://singcore.com/news/pre-built-torsionbox-inserts-at-lowes/attachment/how-to-glue-singtorsion-box-available-at-lowes-wood-frame-2)

3. Selanjutnya Honeycomb Paper diposisikan di antara kedua bingkai kayu yang kemudian dapat diregangkan. Proses Peregangan Honeycomb Paper dapat dilakukan dengan 2 cara, yaitu:

a. Proses Pengembangan Mekanik

Mesin digunakan untuk memperluas Honeycomb Paper, menyesuaikan strukturnya dan dipotong sesuai dengan kebutuhan. Terdapat perbedaan antara "ekspansi dingin" dan "ekspansi hangat".

Dengan pengembangan dingin, Honeycomb Paper diregangkan secara mekanis dengan cara yang sama seperti cara manual. Honeycomb Paper tidak harus diperbaiki dengan staples, karena meregang kembali ke lebar yang diinginkan dengan overstretching.

Dengan pengembangan hangat, Honeycomb Paper dimasukkan ke dalam oven. Kelebihan dari metode ini adalah tingkat kelembaban dapat diminimalisir dari kertas. Dengan cara ini Honeycomb Paper dapat menyerap lebih banyak kelembaban dari lem dengan hasil bahwa selama fase pengepresan papan akan merekat dengan lebih sempurna.

b. Proses Pengembangan Manual

Sesuai dengan namanya, metode ini dilakukan dengan cara manual. Metode juga dapat diaplikasikan pada pembuatan pintu Honeycomb namun dalam proses pembuatannya dibutuhkan banyak tenaga manusia dan kurang cocok digunakan dalam produksi dalam jumlah yang besar.

Tahap terakhir yaitu dengan merekatkan papan HVL yang telah diberi lem pada sisi yang ingin direkatkan pada struktur bingkai kayu dan Honeycomb Paper yang akan dilanjutkan ke tahap pengepressan. Tahap pengepressan akan meningkatkan presentase keberhasilan proses pengeleman. Dengan demikian, alat ini juga akan menghemat biaya, waktu, serta energi yang dulunya terbuang akibat kegagalan proses pengeleman tanpa clamp press.

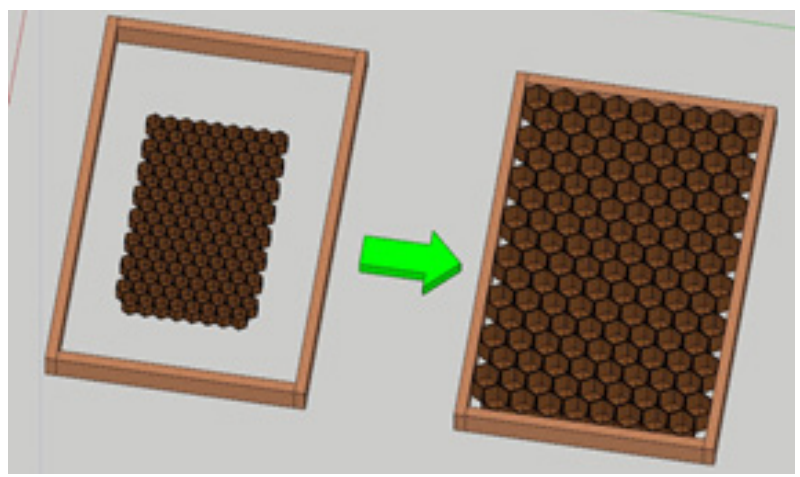

Gambar 3. Ilustrasi Proses Pelebaran Honeycomb Paper Guna Menyesuaikan Ukuran dengan Bingkai Kayu (Sumber: Peneliti)

\section{Cara Pembuatan Panel Honeycomb Struktural Ringan}

1. Pertama yang harus dipersiapkan alat dan bahannya :

- 4 lembar kertas A4 normal (atau ukuran serupa)

- Penggaris

- Dua warna pena yang berbeda

- Gunting kertas atau perangkat lain untuk memotong lembaran kertas lurus dan tepat

- Lem - Ini harus cukup cair untuk menyebar di atas kertas tetapi tidak terlalu cair sehingga meresap melalui selembar kertas

- Gunting atau pisau kerajinan

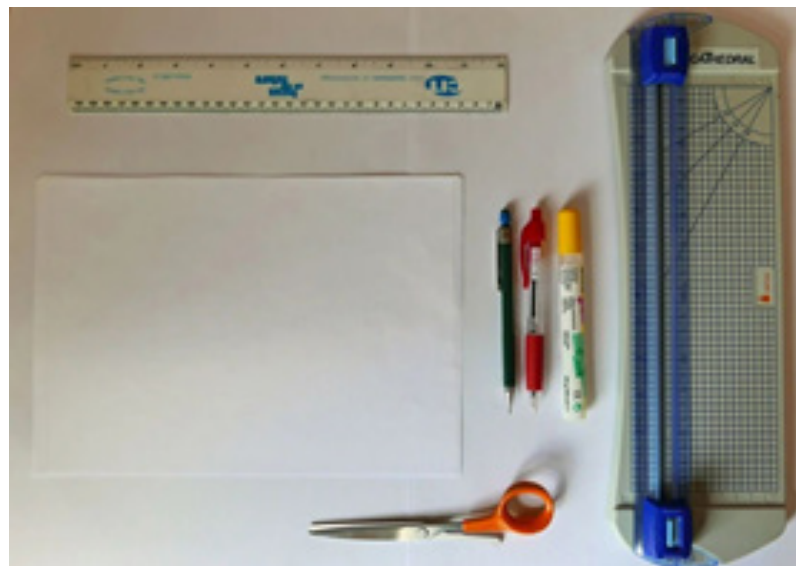

Gambar 4.Bahan-bahanyangdigunakan untuk membuat panel Honeycomb. (Sumber: Peneliti) 
2. Gambar garis-garis pada selembar kertas. Spasi jarak 2,5 cm dan untuk setiap baris kedua gunakan pena merah. Berikutnya ulang hal yang sama pada kertas kedua atau agar lebih praktis dapat dilakukan dengan memfotokopi garis yang pertama yang sudah dibuat.

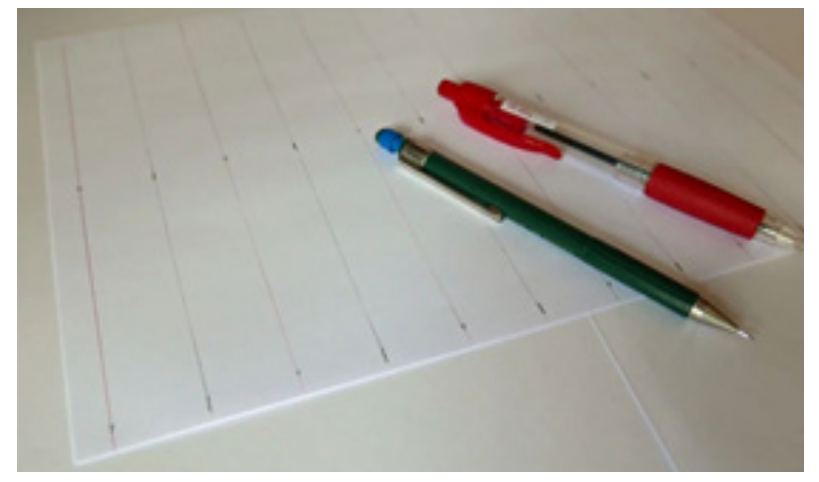

Gambar 5. Proses pembuatan garis-garis untuk membuat panel Honeycomb. (Sumber: Peneliti)

3. Tempelkan lem pada tiap satu baris, kemudian lompati satu baris dan beri lem pada baris berikutnya pada lembar kertas yang sudah diberi garis seperti gambar.

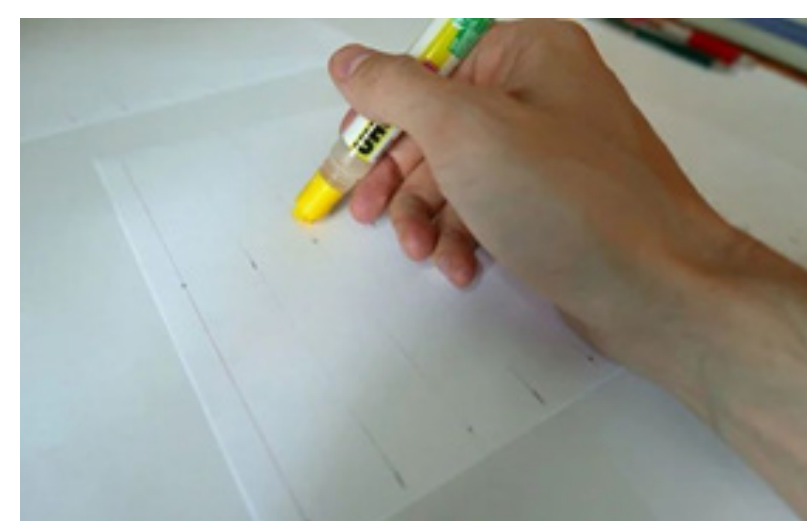

Gambar 6. Proses pemberian lem pada garis yang sudah di buat pada langkah sebelumnya. (Sumber: Peneliti)

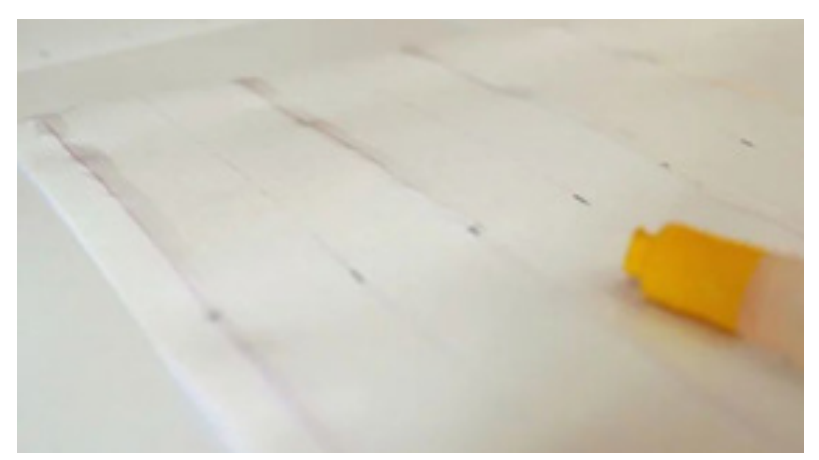

Gambar 7. Kertas Sudah diberi lem. (Sumber: Peneliti)
4. Ambil lembar kertas kedua dan letakkan di atas kertas lembar pertama. Garis-garis pada lembar kertas kedua harus menghadap ke atas dan garis-garis tersebut harus sejalan dengan garis-garis pada lembar di bawahnya. Letakkan buku/benda datar yang berat di atas dua lembar dan tinggalkan sampai lemnya menempel. Pada gambar kedua, dapat dilihat seperti apa lembaran-lembaran itu ketika disorotkan ke cahaya setelah kedua kertas direkatkan dengan lem. Kertas ini direkatkan bersama di setiap baris kedua.

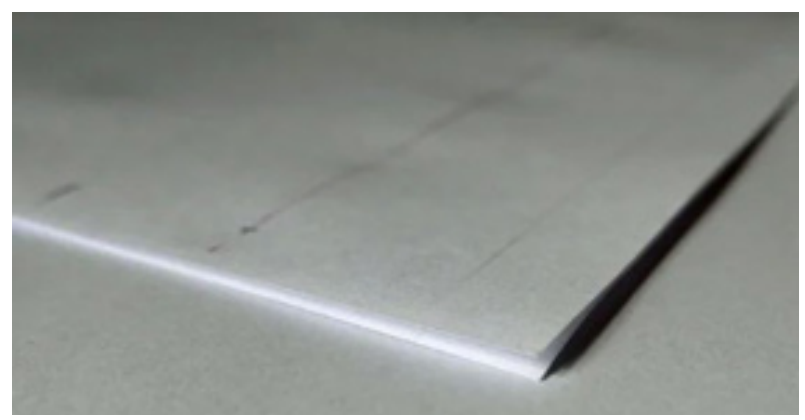

Gambar 8. Tumpuk kedua kertas yang sudah diberi garis.

(Sumber: Peneliti)

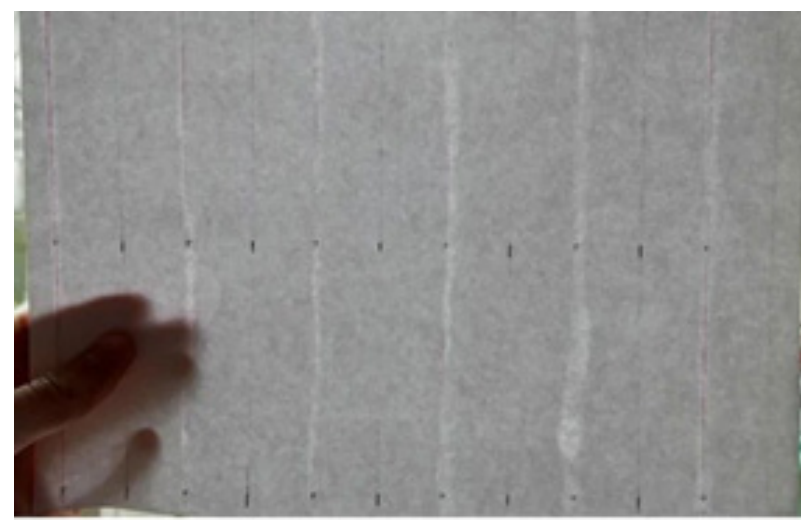

Gambar 9. Sorotkan kertas yang sudah ditumpuk ke arah cahaya.

(Sumber: Peneliti)

5. Ambil kertas yang sudah direkatkan satu dengan yang lainnya dan gunakan gunting kertas atau dapat dengan menggunakan cara lain untuk memotong menjadi selebar sekitar $1,5 \mathrm{~cm}$. Lebar yang tepat penting untuk diperhatikan, sehingga setiap strip memiliki lebar yang sama. 


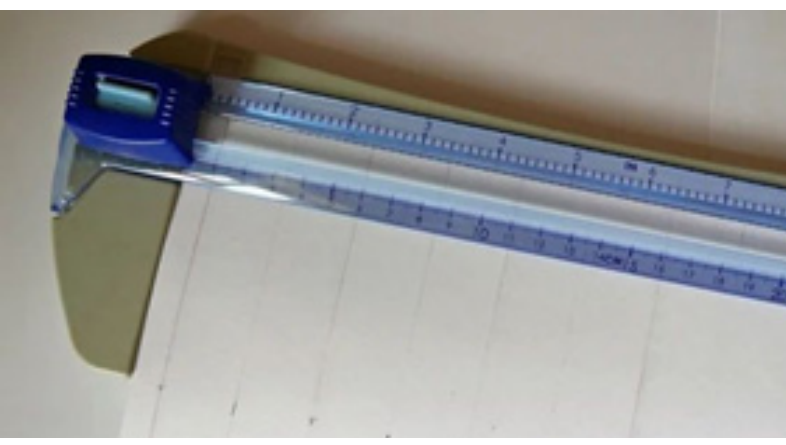

Gambar 10. Potong kertas sesuai dengan garis yang sudah dibuat. (Sumber: Peneliti)

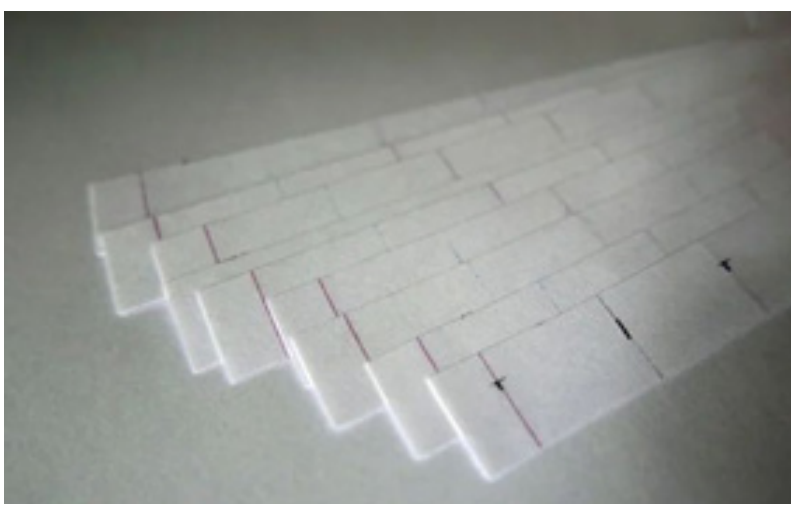

Gambar 11. Kertas yang sudah terpotong. (Sumber: Peneliti)

6. Ambil strip pertama dan rekatkan lem ke setiap baris kedua tetapi bukan garis warna yang sama dengan yang di tempel pertama, kali. Selanjutnya rekatkan lem ke garis hitam. Letakkan strip berikutnya di atasyang pertama sehingga menempel. Kemudian tambahkan lem pada setiap strip sampai semua strip direkatkan dalam tumpukan seperti pada foto kedua di bawah. Ketika semua kertas sudah menempel pastikan bahwa semua tepi selaras dan kemudian letakkan kembali di bawah buku/benda datar yang berat yang berat sampai lem telah kering.

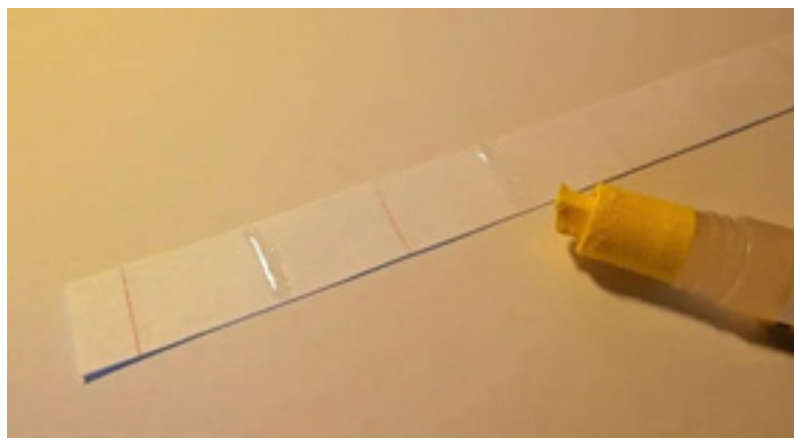

Gambar 12. Kertasyang sudah di potong diberi lem pada garis berwarnamerah.

(Sumber: Peneliti)
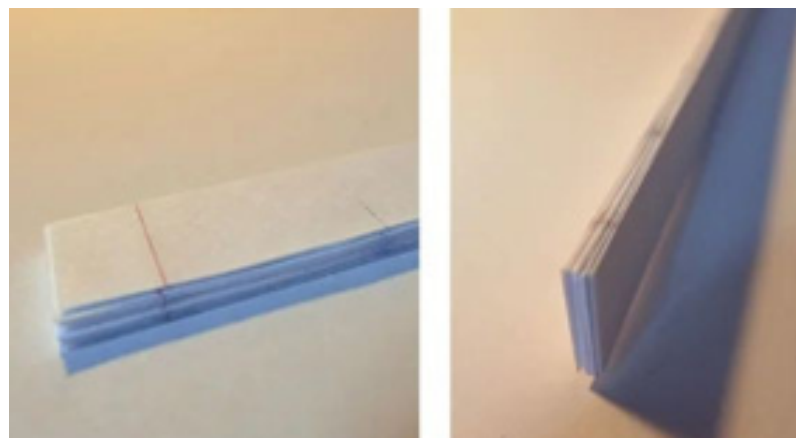

Gambar 13. Kertas yang sudah diberilem di garismerah direkatkandengan kertas lain pada garis berwarna hitam. (Sumber: Peneliti)

7. Setelah lem sepenuhnya kering, mulai buka sarang madu. Beberapa lem akan bocor dan menyatukan honeycomb di tempat-tempat yang tidak seharusnya, sehingga perlu untuk memisahkan tempat-tempat ini dengan hatihati sampai didapatkan hasil yang diinginkan. Selanjutnya sarang madu perlu diregangkan sampai tetap dalam posisi terbuka sendiri.

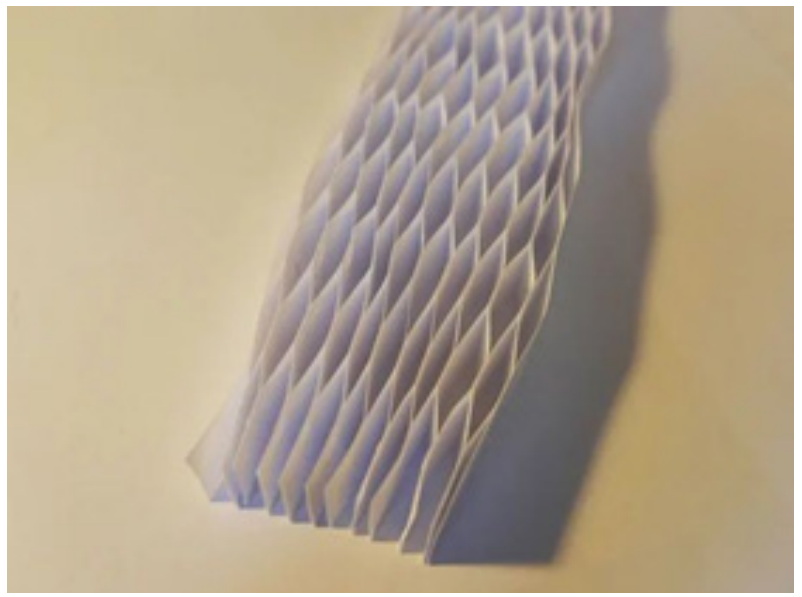

Gambar 14. Buka kertas yang sudah di lem. (Sumber: Peneliti)

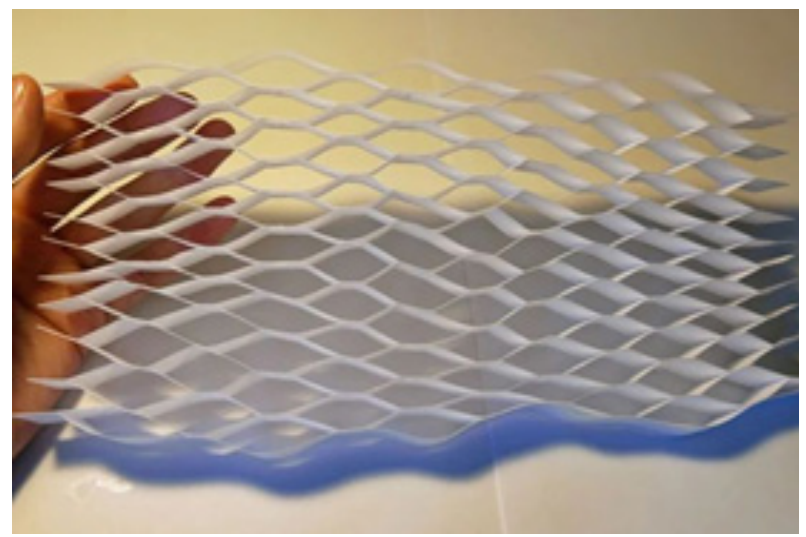

Gambar 15. Posisi kertas setelah dibuka. (Sumber: Peneliti) 
ARS: Jurnal Seni Rupa dan Desain - Volume 23, Nomor 1 Januari - Maret $2020 \quad 45 \mid$

8. Ambil kertas ke-3 dan tempelkan lem di atasnya hingga cukup untuk menutupi sarang lebah. Tempatkan sarang lebah yang direntangkan di atas lembaran kemudian rekatkan dan tekan dengan lembut sehingga setiap bit sarang madu menempel pada lembaran kertas di bawahnya. Tempel lembar kertas ke-4 dan letakkan yang ini di atas sarang madu. Ratakan kedua sisi dengan menggosok lembut dan kemudian letakkan beberapa buku/benda datar yang berat di atas dan tunggu lem hingga kering. Balikkan beberapa kali selama 20 menit pertama sehingga lem tidak semua berjalan dalam satu arah.

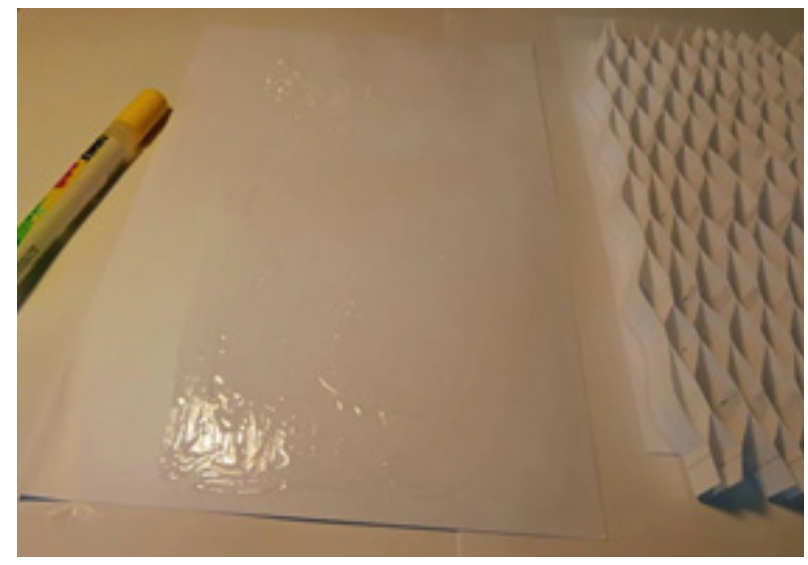

Gambar 16. Beri lem pada selembar kertas kosong. (Sumber: Peneliti)

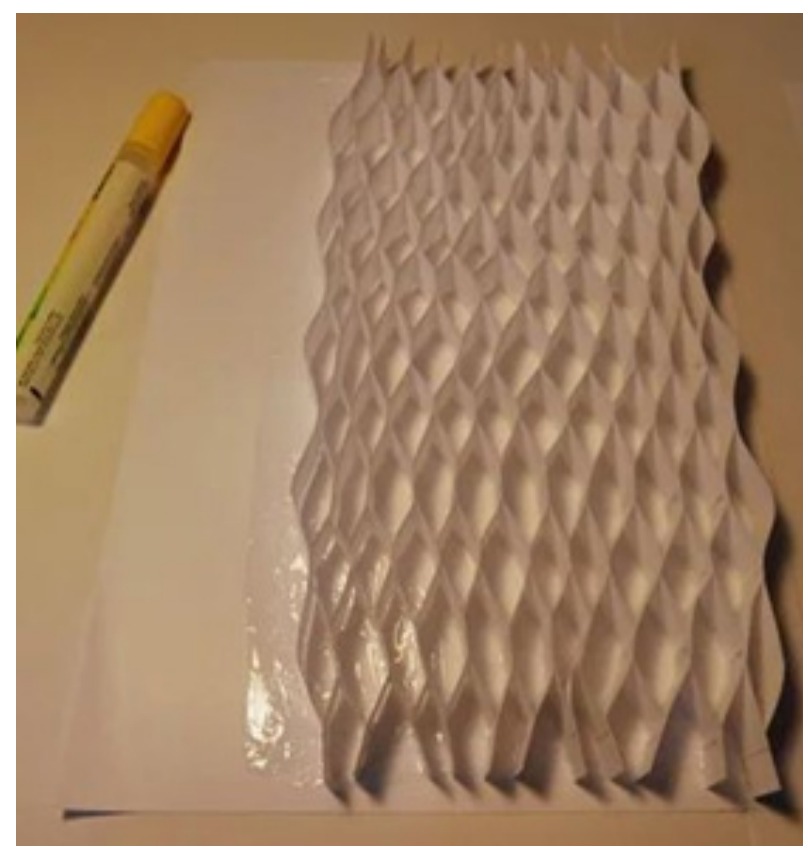

Gambar 17. Ketas yang sudah dibuka diletakkan di selembar kertas yang sudah diberi lem. (Sumber: Peneliti)

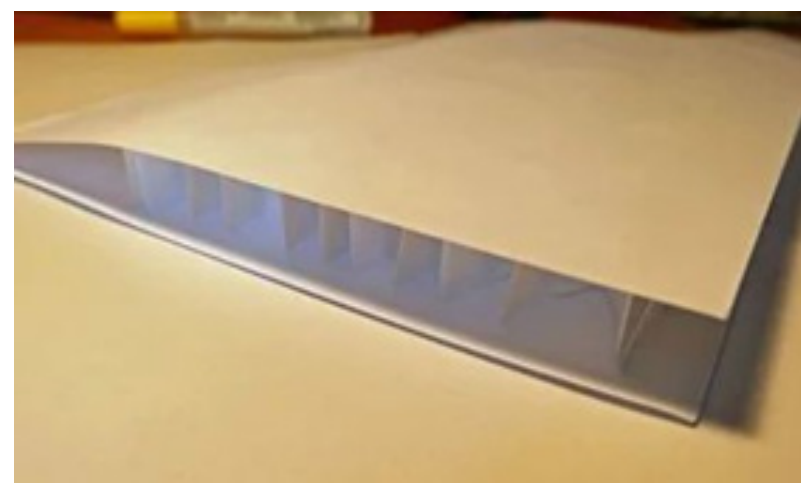

Gambar 18. Kertas yang sudah di beri lem diletakkan di tutupkan pada kertas yang sudah dibuka. (Sumber: Peneliti)

9. Saat lem diberikan, agar lebih rapi potong kelebihan kertas dari lembar atas dan bawah. Jika ingin menempelkan potongan kertas atau kartu pada tiap sisi-sisinya agar sarang madu-nya tidak terlihat, hal ini dapat dilakukan. Tetapi hal ini hanya optional saja dan tidak harus dilakukan. Untuk finishing bisa mengecat panel, mengoleskan resin anti air atau cukup gunakan panel apa adanya. Jika ingin membuat panel yang lebih besar, dapat dengan melakukan langkah pertama menggunakan lebih dari 2 lembar kertas atau lebih dengan merekatkan 4 atau 6 atau 8 lembar bersama-sama dan kemudian memotong strip tebal pada gunting kertas. Untuk merekatkan garis, warna alternatif saat Anda menambahkan setiap lembar, selalu gunakan nomor genap. Jika merekatkan 3 atau 5 lembar bersama-sama maka ketika memotong strip dan mulai menempelkannya bersama-sama, maka akan ditemukan bahwa kertas yang ditempel, garis merah menjadi garis merah dan honeycomb tidak akan berfungsi dengan baik ketika Anda mencoba membukanya.

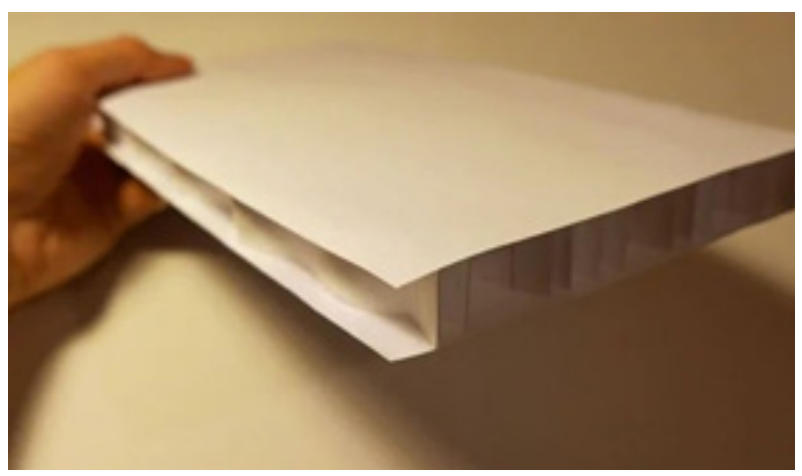

Gambar 19. Posisi kertas yang dibuka setelah diberi kertas pada bagian atas dan bawah. (Sumber: Peneliti) 


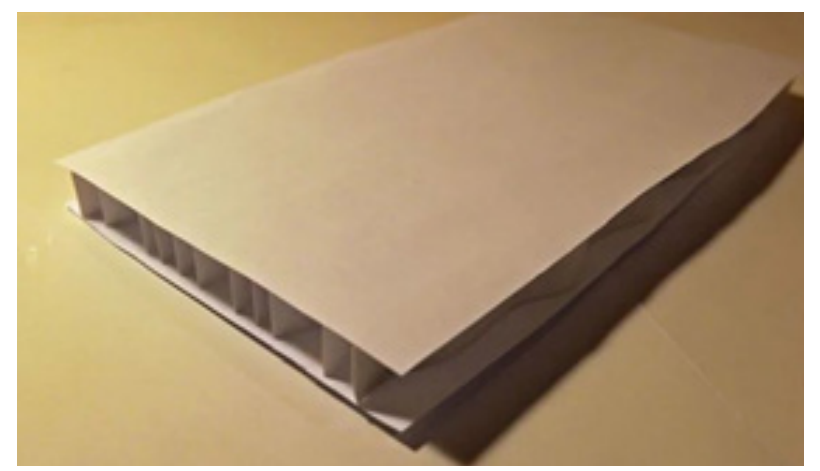

Gambar 20. Posisi kertas yang dibuka setelah diberi kertas pada bagian atas dan bawah (bagian alas kertas yang berlebih dapat dipotong agar lebih rapi) (Sumber: Peneliti)

10. Langkah terakhir ini yaitu uji beban kecil untuk menunjukkan kepada komunitas Instructables seberapa kuat dengan 4 lembar kertas A4 ketika direkatkan dengan geometri sarang lebah. Pengujian ini dilakukan tidak sampai hancur, namun hanya dengan 5 kilogram buku.

Hal ini cukup bagus untuk 4 lembar kertas A4. Panel tidak menekuk sehingga diyakini panel ini memiliki prospek untuk bisa lebih dari ini. Panel seperti ini terbuat dari karton dan dibuat sedikit lebih tebal cukup kuat untuk diberdirikan.

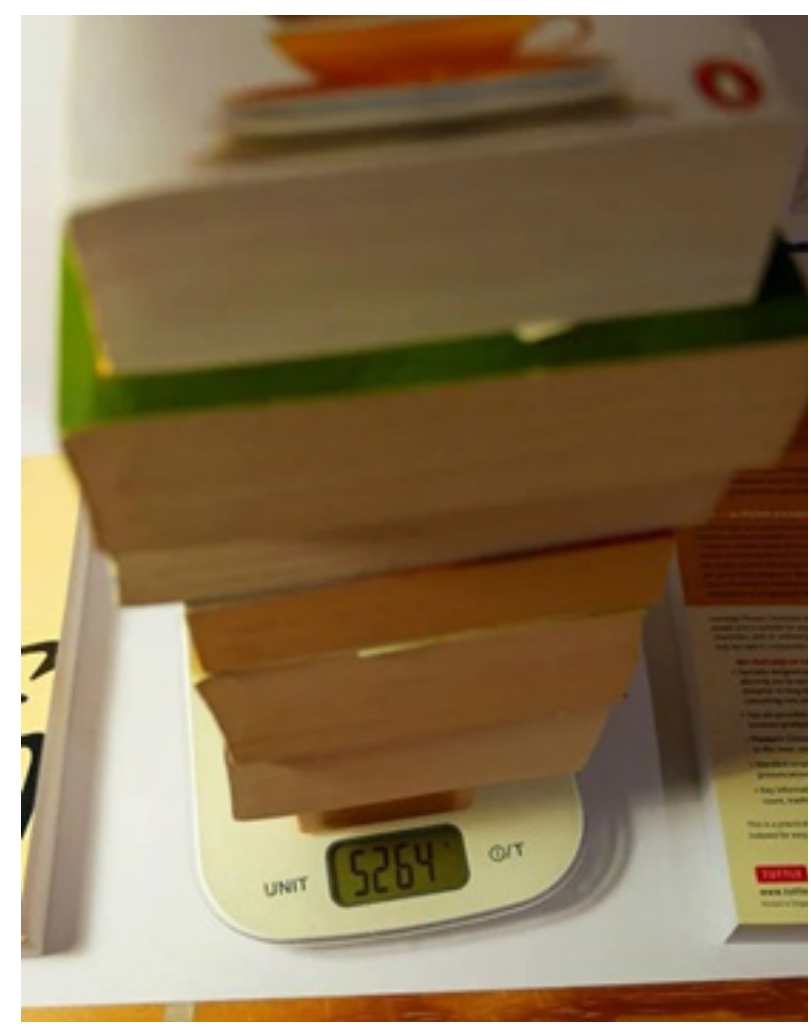

Gambar 21. Buku yang digunakan untuk uji beban. (Sumber: Peneliti)

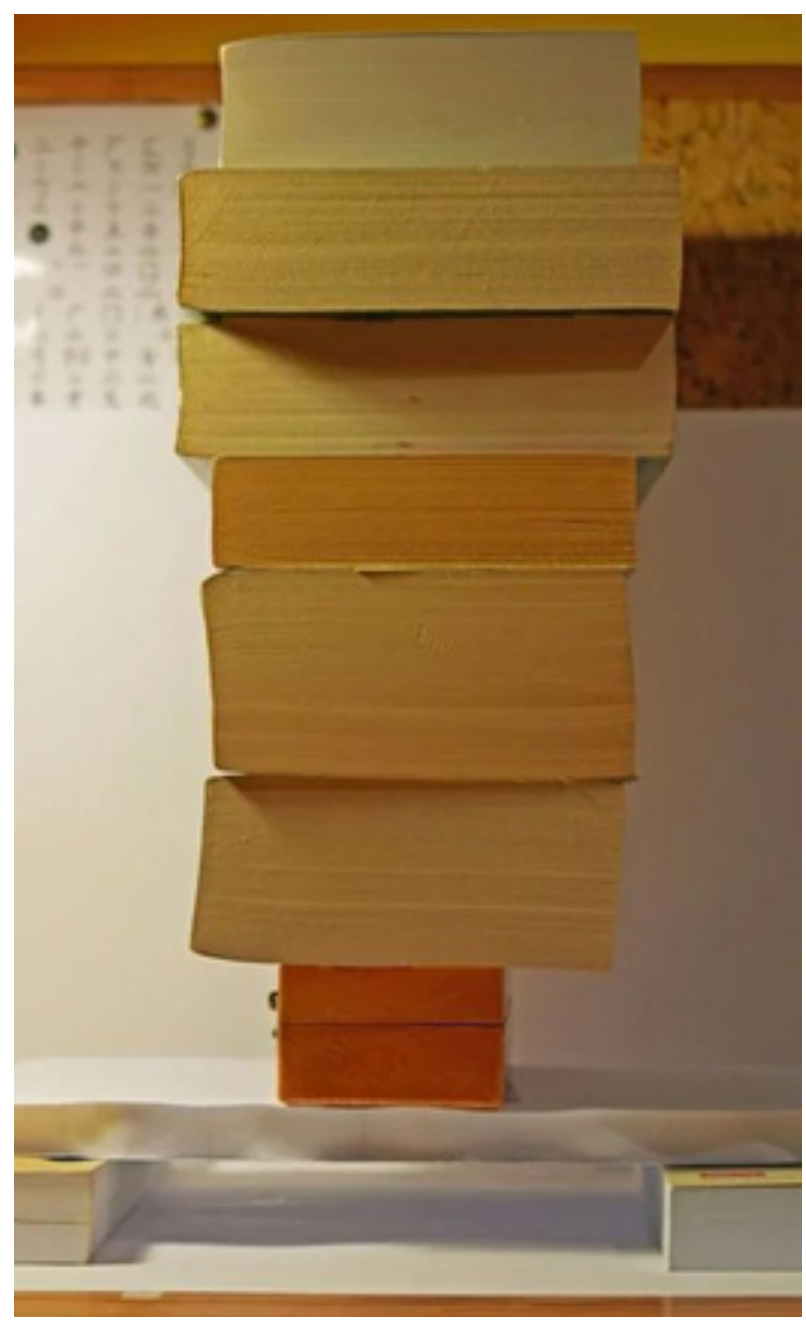

Gambar 22. Buku diletakkan diatas panel Honeycomb untuk uji beban.

(Sumber: Peneliti)

11. Sebagai catatan, panel honeycomb ini terlihat cukup bagus ketika disorot dengan cahaya. Selain itu hal ini dapat dipertimbangkan untuk digunakan untuk panel pembuatan jendela/ pintu sebagai alternatif dari kayu/ aluminium, panel ini juga dapat menjadi alternatif untuk penutup jendela dll.

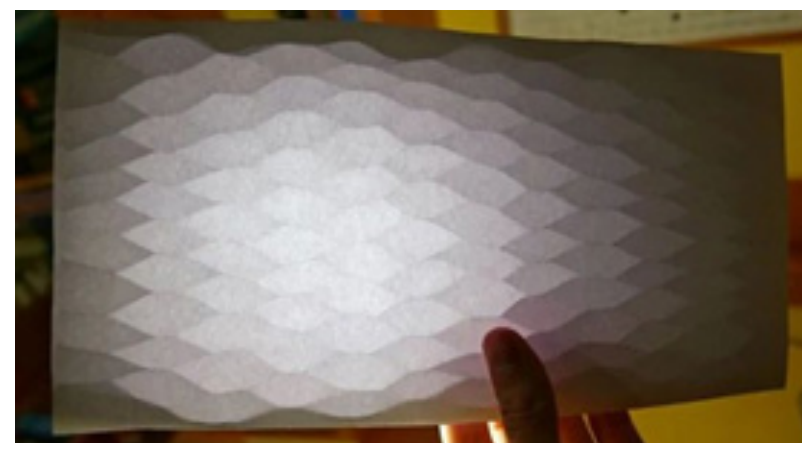

Gambar 23. Panel Honeycomb saat disorot dengan cahaya.

(Sumber: Peneliti) 


\section{Kelebihan Honeycomb Paper}

Honeycomb Panel ini akan memberikan karateristik yang sangat bagus pada kontruksi funiture, seperti :

- Kestabilan yang sangat tinggi, tidak mudah mengakami perubahan bentuk.

- Mempunyai kekuatan bending yang sangat optimum.

- Mempunyai kekuatan yang tinggi sesuai dengan perbandingan berat.

- Daya dukung beban tinggi.

- Dapat diproduksi dalam waktu yang tak terhingga, mengingat mudahnya untuk mendapatkan bahan baku.

- Mempunyai daya tahan lama.

- Transportasi lebih mudah karena memiliki beban yangringan.

- Mudah di rakit.

Lightweight Honeycomb panel ini dapat bertahan dengan usia yang sama seperti pada solid wood panel. Sementara itu dapat dikatakan bahwa berat dari honeycomb panel ini hanya $30 \%$ dari berat solid wood panel dan termasuk kedalam golongan panel yang menunjukkan kepadatan kurang dari $1100 \mathrm{lbs} / \mathrm{m}^{3}$ sehingga termasuk dalam kategori panel yang ringan.Cellsize

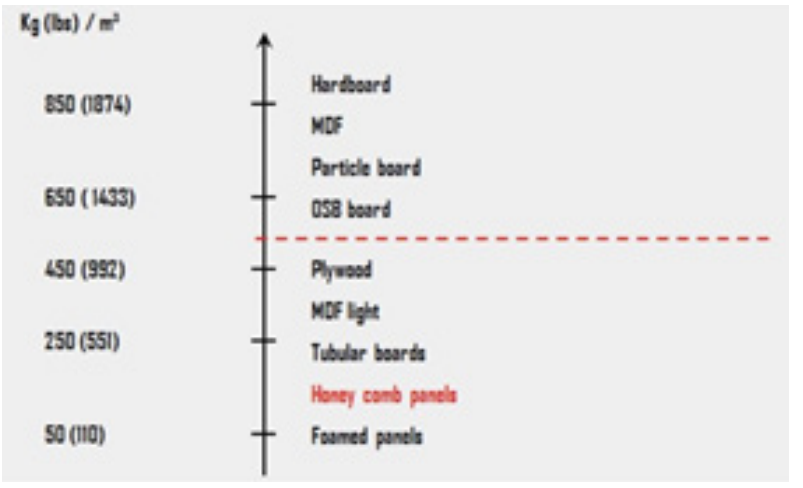

Gambar 24. Light Weight Panel Category (Sumber : http://www. ecoglobepackaging.com/honeycombcore.html)
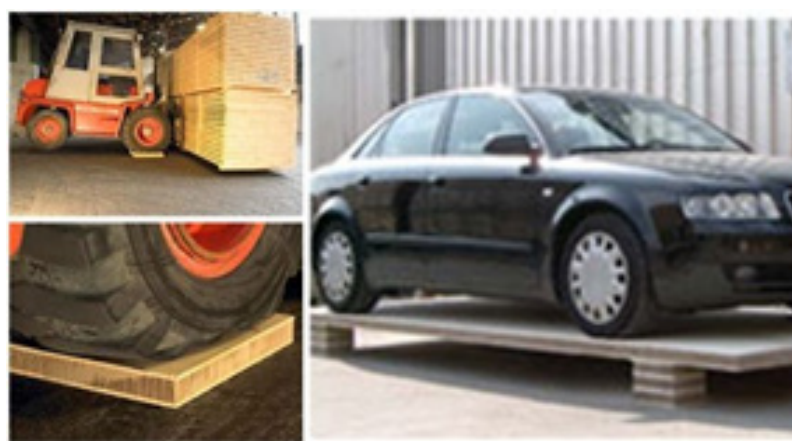

Gambar 25. Bukti Honeycomb memiliki daya dukung beban tinggi

(Sumber:http://www.ecoglobepackaging.com/ honeycombcore.html)

\section{Honeycomb Paper}

Kertas Honeycomb terdiri dari berbagai ukuran cell size sesuai dengan penggunaan. honeycomb dapat di aplikasikan di industri Mobil, door industry, dan juga untuk industri interior.

Yang dimaksudkan dengan cell size pada Honeycomb Paper Core ini adalah jarak antara dinding pada glue line bawah ke glue line bagian atas pada saat dikembangkan secara ideal, untuk mengetahui apakah pengembangan (expanding) sempurna kita dapat menggunakan lingkaran dengan diameter sesuai dengan cell size dan kita letakkan ditengah antar glue line bawah dan glue line atas dan lingkaran harus menyentuh dinding hoenycomb core paper disekitar glue line. Sebagai contoh jika kita memakai kertas Honeycomb ini dengan cell size $22 \mathrm{~mm}$, maka kita harus menggunakan lingkaran dengan diameter $22 \mathrm{~mm}$ dan diletakkan ditengah-tengah cell.

Cell size honeycomb:

- $\quad$ Paper Honeycomb Cell Size $8 \mathrm{~mm}$

- Paper Honeycomb Cell Size $10 \mathrm{~mm}$

- Paper Honeycomb Cell Size $12 \mathrm{~mm}$

- Paper Honeycomb Cell Size $14 \mathrm{~mm}$

- Paper Honeycomb Cell Size $16 \mathrm{~mm}$

- Paper Honeycomb Cell Size $20 \mathrm{~mm}$

- Paper Honeycomb Cell Size $22 \mathrm{~mm}$

- Paper Honeycomb Cell Size $26 \mathrm{~mm}$

- Paper Honeycomb Cell Size $32 \mathrm{~mm}$

- Paper Honeycomb Cell Size $41 \mathrm{~mm}$

Sedangkan untuk lebar honeycomb paper adalah:

- Honeycomb Core Paper Width 1000 mm

- Honeycomb Core Paper Width 1070 mm

- Honeycomb Core Paper Width 1250 mm

- Honeycomb Core Paper Width 1300 mm

- Honeycomb Core Paper Width 1400 mm

- Honeycomb Core Paper Width 1600 mm

- Honeycomb Core Paper Width 2600 mm

- Honeycomb Core Paper Width 2800 mm.

\section{Hasil Jadi Honeycomb Paper}

Aplikasi kertas honeycomb paper:
- Doors
- Desks
- Tables
- Shelves
- Partitions
- Shopfitting
- Cabinet carcass
- Ecological factor
- Kitchen worktops
- Conference tables
- Wardrobe sliding doors 

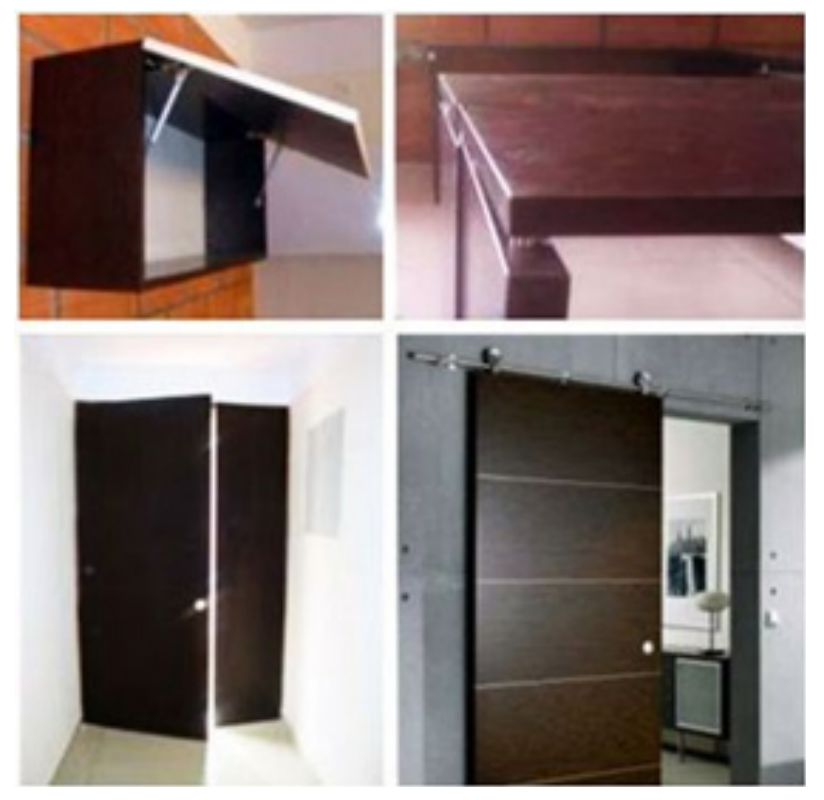

Gambar 26. Penerapan Honeycomb Paper Pada Pintu dan Pintu Rak.

(Sumber:http://www.ecoglobepackaging.com/ honeycombcore.html)

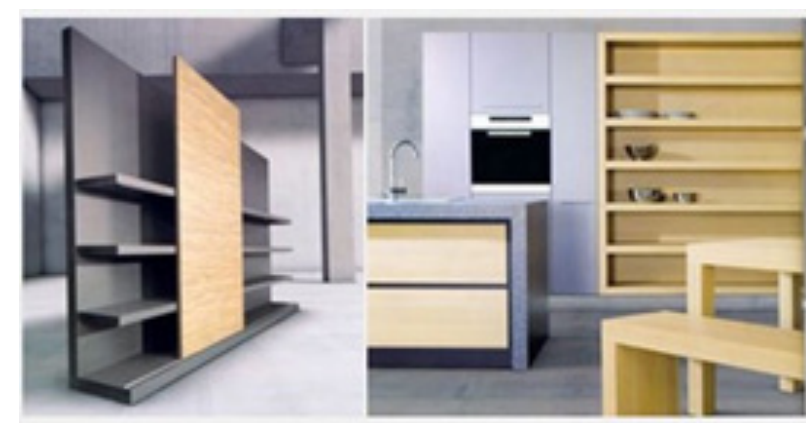

Gambar 27. Penerapan Honeycomb Paper pada rak, lemari, meja, dan kursi

(Sumber:http://www.ecoglobepackaging.com/ honeycombcore.html)

\section{Kesimpulan}

Penggunaan Honeycomb Paper memiliki banyak keuntungan pada proses produksi pembuatan bahan dasar pintu. Keuntungan yang diperoleh yaitu biaya produksi yang rendah dan proses produksi yang simpel \& tidak membutuhkan keahlian khusus. Dari segi kualitas produk yang dihasilkan memiliki karakteristik bobot material yang ringan namun tetap mempertahankan kualitas konstruksi produk yang kokoh dan tahan lama. Tidak hanya itu penggunaan Honeycomb Paper sebagai bahan dasar pembuatan pintu juga meminimalisir penggunaan kayu sehingga dapat dikatakan penggunaan Honeycomb Paper merupakan produk yang ramah lingkungan.

\section{Ucapan Terima Kasih}

Dihaturkan kepada beberapa pihak:

a. Tuhan Yang Maha Esa karena rahmatnya kami dapat menyelesaikan karya tulis ini.

b. Dosen mata kuliah seminar Ibu Dr. Yusita Kusumarini, S.Ds., M.Ds.

c. PT. Alpha Utama Mandiri telah berkenan kami wawancara dan berbagi info terkait Honeycomb Paper

d. Institut Seni Indonesia Yogyakarta yang telah menerima karya tulis kami dengan tangan terbuka dan dapat dipublikasikan dalam jurnal ARS : Jurnal seni rupa dan desain

Kami menyadari bahwa karya tulis ini masih jauh dari sempurna. Oleh sebab itu kami mengharapkan kesediaan Bapak/Ibu dan pembaca sekalian agar dapat memberikan kritik dan saran yang membangun demi kesempurnaan karya tulisini.

Akhir kata, kami mohon maaf yang sebesarbesarnya apabila dalam penyusunan karya tulis ini terdapat banyak kesalahan-kesalahan sertakekurangan-kekurangan. Semoga karya tulis ini dapat bermanfaat.

\section{Kepustakaan}

Lexy, J Moleong, Metode Penelitian Kualitatif

(Bandung: Remaja Rosda Karya, 2007)

Moh. Nazir, Metode Penelitian (Jakarta: PT. Ghalia Indonesia, 2003)

Susanti, Asih, Sistem Pendukung Keputusan Pemilihan Jenis Kayu Untuk Bahan Baku Mebel Dengan Menggunakan Metode Simple Additive Weighting, Undergraduate Thesis, Universitas Muhammadiyah Gresik. (2014)

Suryabrata, S., Metodologi Penelitian, (Jakarta: PT. Raja Grafindo Persada, 2011 